\title{
Cyclonic cold-core eddy in the eastern North Atlantic. III. Zooplankton*
}

\author{
W. Beckmann ${ }^{1}$, A. Auras ${ }^{2}$, Ch. Hemleben ${ }^{2}$ \\ ${ }^{1}$ Institut für Hydrobiologie und Fischereiwissenschaft der Universität Hamburg, Zeiseweg 9, D-2000 Hamburg 50, \\ Federal Republic of Germany \\ ${ }^{2}$ Institut und Museum für Geologie und Paläontologie der Universität Tübingen, Sigwartstr. 10, D-7400 Tübingen, \\ Federal Republic of Germany
}

\begin{abstract}
Horizontal and vertical zooplankton distribution in a 1 mo old cold-core eddy in the eastern North Atlantic were investigated during May 1985. Samples were taken at 3 stations across the eddy down to $1000 \mathrm{~m}$ depth by vertical tows with a multiple opening/closing net using 2 different mesh sizes $(100$ and $300 \mu \mathrm{m})$. Reference data were available for 3 other stations in ambient water. Special attention was paid to the distribution of pteropods and foraminiferans. In the centre of the eddy distinctly higher concentrations of the euthecosomatous pteropod Limacina retroversa were observed compared to the eddy periphery or the ambient water. Extremely high numbers of large specimens ( $>600 \mu \mathrm{m}$ in height) were caught at depths between 100 and $400 \mathrm{~m}$ whereas smaller specimens $(60$ to $150 \mu \mathrm{m}$ in height) resided within the upper $100 \mathrm{~m}$. In the eddy periphery small specimens prevailed and the population was restricted mainly to the upper $100 \mathrm{~m}$ of the water column. This remarkable distribution pattern of $L$ retroversa can be interpreted as governed by the temperature environment and food supply
\end{abstract}

\section{INTRODUCTION}

Rings or eddies represent discrete temporary, mesoscale environments in the oceans. When they cut off from a current or front meander, they are transported into a region with different water characteristics where they may move over long distances. In the North Atlantic, the biology of eddies had until 1985 been investigated only in its western part, where a main area of eddy activity exists along the Gulf Stream. Intensive ecological studies in Gulf Stream rings showed that they act as vehicles for species to cross their natural biogeographical boundaries. The formation, ageing, and decay of a ring are reflected by regular patterns in the population dynamics of expatriate zooplankton and micronekton and by a progressive immigration of animals from the ambient water (e.g. Wiebe et al. 1976 , The Ring Group 1981, Wiebe 1982, Wiebe \& Flierl 1983, Wormuth 1985).

In the eastern North Atlantic Kupferman et al. (1986) recently observed the formation of a large ring structure during April 1985 as 'the eastern counterpart of the Gulf Stream cold-core eddies'. A ca $300 \mathrm{~km}$ long and $40 \mathrm{~km}$ wide meander had formed at the Polar Front extending to the southeast. One mo later, in May 1985, the ring had at least partially been separated from the polar Front and could be investigated for a second time during Cruise 70/III of RV Meteor within the framework of the 2 research programmes NOAMP IV (Nord-Ost Atlantisches Monitoring Programm) and BIOTRANS II/2 (BIOlogical vertical TRANSport and energetics in the benthic boundary layer of the deep sea). In the vicinity of $48^{\circ} 50^{\prime} \mathrm{N}$ and $21^{\circ} 20^{\prime} \mathrm{W}$ the eddy now had a diameter of about $100 \mathrm{~km}$ and extended down to at least $2500 \mathrm{~m}$ depth, showing a vertical structure of interleaving water masses probably representing conditions from the area of origin (Mittelstaedt 1987: this volume). Seasonal surface warming in the range of about 1 to $2^{\circ} \mathrm{C}$ had occurred since the measurements of Kupferman et al. (1986) 3 wk before.

In addition to physical oceanographic investigations carried out by colleagues from the Deutsches Hydrographisches Institut (Mittelstaedt 1987), the BIOTRANS group took the unique opportunity for a short simultaneous biological survey. On a transect across the eddy, the upper $200 \mathrm{~m}$ of the water column was investigated for nutrients, phyto- and bacterioplankton (Lochte \& Pfannkuche 1987 [preceding article]). On an

\footnotetext{
- BIOTRANS Publication No. 3
} 
extended scale of depth ranges, this paper describes some conspicuous distribution patterns exhibited by the zooplankton community.

\section{MATERIAL AND METHODS}

Vertical zooplankton hauls were taken with a multiple opening/closing net (Weikert \& John 1981). The system had a collecting area of $0.25 \mathrm{~m}^{2}$ and was equipped with 5 nets $(300 \mu \mathrm{m}$ or $100 \mu \mathrm{m}$ mesh size) which were sequentially operated via conductor cable. Three of the sample locations across the eddy were investigated with both net types: one in the eddy centre, and two in the peripheral water mass (Table 1). All stations were part of the transect investigated by Mittelstaedt (1987) and Lochte \& Pfannkuche (1987). The depth intervals sampled were 0 to 100,100 to 200 , 200 to 400,400 to 700 , and 700 to $1000 \mathrm{~m}$. The sampling depth was determined by the length of the wire; the $300 \mu \mathrm{m}$ nets were towed at a speed of 30 to $40 \mathrm{~m} \mathrm{~min}^{-1}$ and the $100 \mu \mathrm{m}$ nets at 20 to $25 \mathrm{~m} \mathrm{~min}^{-1}$.

Stn 159 was sampled twice with $300 \mu \mathrm{m}$ nets. Unfortunately, the $300 \mu \mathrm{m}$ net at the 200 to $400 \mathrm{~m}$ depth interval was damaged in both cases, thus no quantitative samples were obtained. The data in Fig. 1 for the other depth intervals at $\operatorname{Stn} 159$ represent mean values from the 2 hauls. Restricted ship-time allowed only one haul at Stns 162 and 164 for each size fraction. At Stn 162 the depth interval 1000 to $700 \mathrm{~m}$ was sampled incompletely with the $100 \mathrm{um}$ net because of net damage. Stns 140 (for $100 \mu \mathrm{m}$ samples), 169 and 170 (for 300 $\mu \mathrm{m}$ samples) served as reference stations, located 100 to $110 \mathrm{n}$ miles ( 185 to $200 \mathrm{~km}$ ) southeast of the eddy (Table 1). Stn 140 was sampled at intervals of 0 to $150 \mathrm{~m}, 150$ to $350 \mathrm{~m}, 350$ to $550 \mathrm{~m}, 550$ to $800 \mathrm{~m}$, and 800 to $1500 \mathrm{~m}$. For the other reference stations (169, $170)$ the sampling procedure integrated the entire water column $(4240 \mathrm{~m}$ at Stn 169 , and $4570 \mathrm{~m}$ at Stn
170). These data were used for standing stock comparisons of the pteropod species Limacina retroversa.

Samples were preserved in a $4 \%$ formalin-seawater solution buffered with hexamethylenetetramine. In the $300 \mu \mathrm{m}$ net hauls protozoans, exoskeletons and animals obviously dead prior to collection were excluded from the counts. Biomass was determined as wet weight using the method of Tranter (1962). Large animals $(>1 \mathrm{~cm})$ were removed before weighing.

In the $100 \mu \mathrm{m}$ net hauls, only pteropods and foraminiferans were considered. The dry counts included all specimens of the size fraction larger than $125 \mu \mathrm{m}$. Due to the large amount of phytoplankton the determination of biomass wet weight was doubtful and thus neglected.

\section{RESULTS}

\section{$300 \mu \mathrm{m}$ samples}

At all stations investigated across the eddy, a general decrease in biomass and total numbers of organisms from the surface down to $1000 \mathrm{~m}$ depth was observed (Table 2). In the upper $200 \mathrm{~m}$ of the water column biomass values were higher in the eddy core than in the peripheral water mass. The total number of organisms, however, did not show any significant trend in its horizontal distribution. The ratio of numbers of organisms to biomass was distinctly higher in the periphery than in the core throughout the upper $700 \mathrm{~m}$.

Copepods, ostracods, and chaetognaths were the main constituent groups in the zooplankton community at all stations on the eddy transect (Fig. 1). Below $400 \mathrm{~m}$, other groups never exceeded $2 \%$ in relative abundance at any site. Comparing different locations, the major taxonomic composition of the zooplankton was relatively uniform in the 2 deepest sampling ranges.

Table 1. Sampling data for stations across the eddy

\begin{tabular}{|lccccc}
\hline Stn & $\begin{array}{c}\text { Mesh size } \\
(\mu \mathrm{m})\end{array}$ & Date & $\begin{array}{c}\text { Sampling time } \\
\text { (local time) }\end{array}$ & Latitude & Longitude \\
\hline 140 (reference) & 100 & 14 May 85 & $0419-0540 \mathrm{~h}$ & $47^{\circ} 26^{\prime} \mathrm{N}$ & $19^{\circ} 40^{\prime} \mathrm{W}$ \\
159 (periphery) & 300 & 18 May 85 & $1600-1632 \mathrm{~h}$ & $48^{\circ} 14^{\prime} \mathrm{N}$ & $21^{\circ} 44^{\prime} \mathrm{W}$ \\
159 (periphery) & 300 & 18 May 85 & $1819-1851 \mathrm{~h}$ & $48^{\circ} 14^{\prime} \mathrm{N}$ & $21^{\circ} 42^{\prime} \mathrm{W}$ \\
159 (periphery) & 100 & 18 May 85 & $2046-2127 \mathrm{~h}$ & $48^{\circ} 14^{\prime} \mathrm{N}$ & $21^{\circ} 42^{\prime} \mathrm{W}$ \\
162 (core) & 100 & 19 May 85 & $0854-0942 \mathrm{~h}$ & $48^{\circ} 51^{\prime} \mathrm{N}$ & $21^{\circ} 18^{\prime} \mathrm{W}$ \\
162 (core) & 300 & 19 May 85 & $1218-1245 \mathrm{~h}$ & $48^{\circ} 50^{\prime} \mathrm{N}$ & $21^{\circ} 20^{\prime} \mathrm{W}$ \\
164 (periphery) & 300 & 19 May 85 & $1914-1938 \mathrm{~h}$ & $49^{\circ} 30^{\prime} \mathrm{N}$ & $21^{\circ} 10^{\prime} \mathrm{W}$ \\
164 (periphery) & 100 & 19 May 85 & $2205-2246 \mathrm{~h}$ & $49^{\circ} 31^{\prime} \mathrm{N}$ & $21^{\circ} 13^{\prime} \mathrm{W}$ \\
169 (reference) & 300 & 21 May 85 & $1632-1908 \mathrm{~h}$ & $47^{\circ} 22^{\prime} \mathrm{N}$ & $19^{\circ} 40^{\prime} \mathrm{W}$ \\
170 (reference) & 300 & 22 May 85 & $0752-1000 \mathrm{~h}$ & $47^{\circ} 29^{\prime} \mathrm{N}$ & $19^{\circ} 43^{\prime} \mathrm{W}$ \\
\hline
\end{tabular}


Table 2. Concentrations of biomass wet weight and numbers of organisms in the upper $1000 \mathrm{~m} ; 300 \mu \mathrm{m}$ nets. For Stn 159 , values from 2 hauls are shown

\begin{tabular}{|c|c|c|c|c|c|c|c|}
\hline \multirow[t]{2}{*}{ Parameter } & \multirow[t]{2}{*}{ Stn } & \multicolumn{5}{|c|}{ Depth $(\mathrm{m})$} & \multirow{2}{*}{$\begin{array}{l}\text { Total standing } \\
\text { stock }(0-1000 \mathrm{~m}) \\
\text { (No. or } \mathrm{g} \mathrm{m}^{-2} \text { ) }\end{array}$} \\
\hline & & $0-100$ & $100-200$ & $200-400$ & $400-700$ & $700-1000$ & \\
\hline \multirow{3}{*}{$\begin{array}{l}\text { A. Biomass } \\
\left(\mathrm{mg} \mathrm{m}^{-3}\right)\end{array}$} & 159 & $72 / 96$ & $24 / 38$ & NA & $16 / 14$ & $7 / 21$ & NA \\
\hline & 162 & 156 & 76 & 32 & 19 & 16 & 40 \\
\hline & 164 & 110 & 60 & 38 & 12 & 99 & 31 \\
\hline \multirow{3}{*}{$\begin{array}{l}\text { B. Total no. of } \\
\text { organisms } \\
\left.\text { (no. } \mathrm{m}^{-3}\right)\end{array}$} & 159 & $311 / 376$ & $85 / 84$ & NA & $23 / 14$ & $4 / 12$ & NA \\
\hline & 162 & 281 & 94 & 39 & 16 & 15 & 54880 \\
\hline & 164 & 299 & 152 & 56 & 22 & 16 & 67640 \\
\hline \multirow{3}{*}{$\begin{array}{l}\text { C. Ratio B/A } \\
\left(\text { no. } g^{-1}\right)\end{array}$} & 159 & $4320 / 3920$ & $3530 / 2210$ & NA & $1420 / 1000$ & $570 / 570$ & NA \\
\hline & 162 & 1800 & 1240 & 1230 & 870 & 940 & 1370 \\
\hline & 164 & 2720 & 2530 & 1470 & 1870 & 1720 & 2180 \\
\hline
\end{tabular}

A conspicuous spatial distribution pattern was exhibited by euthecosomatous pteropods. For all depth ranges sampled, highest concentrations were found in the core of the eddy where almost $100 \%$ of the pteropod assemblage could be assigned to Limacina retroversa (Table 3 ). In the eddy periphery and at the reference stations some other specimens of the genera Diacria and Clio occurred. At Stns 159 and 164 (eddy periphery) $L$. retroversa concentrated mainly within the upper $100 \mathrm{~m}$ of the water column, and small specimens $(<600 \mu \mathrm{m}$ in height) formed the bulk of individuals. In the centre of the eddy, however, large specimens ( $>600 \mu \mathrm{m}$ in height) prevailed, representing more than $95 \%$ of the total amount of $L$. retroversa at depths between 100 and $400 \mathrm{~m}$ where highest concentrations of the species occurred $(14.5 \%$ of total zooplankton number in the 100 to $200 \mathrm{~m}$ layer and $17.2 \%$ of total zooplankton number in the 200 to $400 \mathrm{~m}$ layer; Fig. 1 and Table 3).
In the upper $100 \mathrm{~m}$, ostracods were poorly represented at all stations. Besides copepods and chaetognaths, only hyperiid amphipods (predominantly juveniles) and jellyfish exhibited relative abundances of more than $2 \%$, which were restricted to the centre of the eddy (Fig. 1).

\section{0 um samples}

In general, the absolute and relative abundances of euthecosomatous pteropods and foraminiferans exhibited an inverse horizontal distributional pattern: pteropods peaked in the eddy core and were least abundant at reference Stn 140, where the foraminiferans were most abundant, decreasing towards the centre of the eddy (Table 4). Both groups exhibited high concentrations in the upper $100 \mathrm{~m}$ layers which were drastically reduced in the deeper sampling intervals (Tables $5 \& 6$ ).
Fig. 1. Relative abundances of main taxa in the zooplankton community at different locations across the eddy $(300 \mu \mathrm{m}$ nets $)$. Values $<2 \%$ were not considered

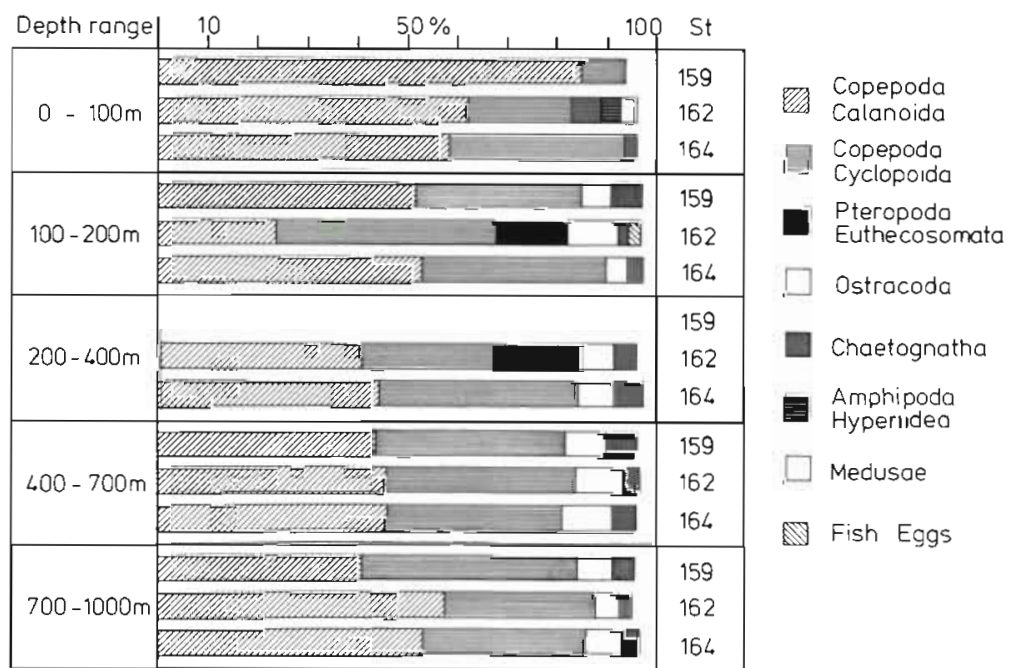


Table 3. Limacina retroversa. Concentrations in different depth ranges across the eddy (numbers per $100 \mathrm{~m}^{3}$ and population standing stocks; $300 \mu \mathrm{m}$ nets. $\mathrm{N}$ : total number $\mathrm{m}^{-2}$; P: percentage of all pteropods. In parentheses: temperature range $\left({ }^{\circ} \mathrm{C}\right.$ ) (after Mittelstaedt 1987). For Stn 159, values for 2 hauls are shown

\begin{tabular}{|c|c|c|c|c|c|}
\hline \multirow[t]{2}{*}{ Depth $(\mathrm{m})$} & \multicolumn{5}{|c|}{ Station no. } \\
\hline & 159 & 162 & 164 & 169 & 170 \\
\hline $0-100$ & $\begin{array}{c}220 / 120 \\
(13.0-11.5)\end{array}$ & $\begin{array}{c}310 \\
(12.5-10.3)\end{array}$ & $\begin{array}{c}120 \\
(13.0-12.0)\end{array}$ & - & - \\
\hline $100-200$ & $\begin{array}{c}8 / 0 \\
(11.5-11.0)\end{array}$ & $\begin{array}{c}1360 \\
(10.3-9.5)\end{array}$ & $\begin{array}{c}8 \\
(12.0-11.3)\end{array}$ & - & - \\
\hline $200-400$ & $\begin{array}{c}\text { NA } \\
(11.0-9.8)\end{array}$ & $\begin{array}{c}670 \\
(9.5-7.5)\end{array}$ & $\begin{array}{c}4 \\
(11.3-10.7)\end{array}$ & - & - \\
\hline $400-700$ & $\begin{array}{c}1 / 1 \\
(9.8-7.9)\end{array}$ & $\begin{array}{c}4^{\circ} \\
(7.5-5.5)\end{array}$ & $\begin{array}{c}0 \\
(10.7-9.5)\end{array}$ & - & - \\
\hline $700-1000$ & $\begin{array}{c}0 / 0 \\
(7.9-5.7)\end{array}$ & $\begin{array}{c}7^{\circ} \\
(5.5-4.3)\end{array}$ & $\begin{array}{c}1 \\
(9.5-7.0)\end{array}$ & - & - \\
\hline$N$ & $230 / 120$ & 3010 & 140 & 1040 & 520 \\
\hline P & 79 & 100 & 60 & - & - \\
\hline
\end{tabular}

Again the most striking observation concerned the occurrence of the pteropod Limacina retroversa, which was the most abundant species in the 0 to $100 \mathrm{~m}$ interval of the eddy core. The ratio of large specimens (> $600 \mu \mathrm{m}$ height) to small specimens (60 to $150 \mu \mathrm{m}$ in height) was in the order of $1: 500$. The pattern of vertical separation of small and large specimens found in the $300 \mu \mathrm{m}$ samples could not be verified: below the 0 to $100 \mathrm{~m}$ interval the abundance of $L$. retroversa decreased drastically and was replaced by Diacria sp. in the ambient water mass. Only a few broken specimens of adults including debris were found.

The absolute numbers of the genera Clio, Diacria and Cavolinia demonstrated a parallel distribution of Clio and Diacria and a reverse distribution of Cavolinia with respect to their abundance in the core, the peripheral water mass and the reference station (Table 5; Fig. 2).

The foraminiferal assemblage comprised 15 species of which only 7 were common (Table 6). The deepwater living, non-spinose species Globorotalia inflata, G. scitula, and G. hirsuta (Fig. 3) and the spinose species $G$. bulloides showed a distinct decrease towards the core. Relative abundances of $G$. bulloides were similar in the core and at the reference station. The percentage of large specimens (test size $>250 \mu \mathrm{m}$ ) was highest in the core sample $(43 \%)$ in contrast to the remaining stations $(17.7$ to $18.9 \%)$. The shallow-living spinose species (G. quinqueloba, Neogloboquadrina incompta) occurred in slightly higher numbers in the eddy compared with the reference site. Globigerinita glutinata exhibited a clear increase in absolute abundance from the eddy towards the surrounding water mass.

\section{DISCUSSION}

Higher zooplankton biomass concentrations in coldcore eddies compared with the surrounding water have been reported as characteristic for young Gulf Stream cold-core rings. These rings originate in the Gulf Stream entrapping Slope Water with a higher plankton biomass content compared to the adjacent Sargasso Sea (Wiebe 1976, 1982, The Ring Group 1981). A similar mechanism, though less pronounced, can be observed in the eastern North Atlantic. In older Gulf Stream cold-core rings the surface biomass is often distinctly less than in the surrounding Sargasso Sea

Table 4. Abundances of pteropods and foraminifers (100 um nets). Note the reverse pattern. $n$ : number of specimens per sample; Pt: pteropods; F: foraminifers

\begin{tabular}{|c|c|c|c|c|c|c|}
\hline \multirow[t]{2}{*}{ Station } & \multicolumn{3}{|c|}{ Surface } & \multicolumn{3}{|c|}{ All intervals } \\
\hline & $\mathrm{nPt}+\mathrm{F}$ & $\%$ Ptero. & $\%$ Foram. & $\mathrm{nPt}+\mathrm{F}$ & $\%$ Ptero. & $\%$ Foram. \\
\hline 159 & 2731 & 38.6 & 61.4 & 3287 & 35.4 & 64.6 \\
\hline 162 & 7218 & 75.1 & 24.9 & 7552 & 73.7 & 26.3 \\
\hline 164 & 4737 & 37.8 & 62.2 & 6231 & 34.7 & 65.3 \\
\hline 140 & 3559 & 3.9 & 96.1 & 5981 & 10.1 & 89.9 \\
\hline
\end{tabular}


Table 5. Absolute abundances of pteropods from all investigated stations $\left(100\right.$ um nets); numbers per $100 \mathrm{~m}^{3}$. The relative abundances of Limacina retroversa emphasize its dominance in surface waters. Lre: L. retroversa; Cli: Clio spp.; Dia: Diacria spp.; Cav: Cavolinia spp.; n: total number of specimens per sample; n $100 \mathrm{~m}^{-3}$. pteropod specimens per $100 \mathrm{~m}^{3}$; $\mathrm{n}$ Lre: total number of specimens of $L$. retroversa; \% Lre: \% of $L$. retroversa per haul; $\%$ surf.: $\%$ of $L$. retroversa in the surface tows

\begin{tabular}{|c|c|c|c|c|c|c|c|c|c|c|}
\hline Stn. & Depth $(\mathrm{m})$ & Lre & $\mathrm{Cli}$ & Dia & Cav & $\mathrm{n}$ & n $100 \mathrm{~m}^{-3}$ & n Lre & $\%$ Lre & $\%$ surf \\
\hline 159 & $\begin{array}{r}0-100 \\
100-200 \\
200-400 \\
400-700 \\
700-1000\end{array}$ & $\begin{array}{r}1032 \\
10 \\
19 \\
10 \\
7\end{array}$ & $\begin{array}{l}0 \\
1 \\
8 \\
8 \\
0\end{array}$ & $\begin{array}{r}11 \\
8 \\
15 \\
19 \\
1\end{array}$ & $\begin{array}{r}11 \\
1 \\
0 \\
3 \\
0\end{array}$ & $\begin{array}{r}1054 \\
20 \\
42 \\
40 \\
8\end{array}$ & $\begin{array}{r}426 \\
80 \\
84 \\
53 \\
10\end{array}$ & 1078 & 92.6 & 97.9 \\
\hline 162 & $\begin{array}{r}0-100 \\
100-200 \\
200-400 \\
400-700 \\
700-1000\end{array}$ & $\begin{array}{r}5386 \\
7 \\
28 \\
39 \\
63\end{array}$ & $\begin{array}{l}1 \\
0 \\
1 \\
1 \\
0\end{array}$ & $\begin{array}{l}0 \\
0 \\
2 \\
0 \\
1\end{array}$ & $\begin{array}{r}37 \\
0 \\
1 \\
0 \\
0\end{array}$ & $\begin{array}{r}5424 \\
7 \\
32 \\
40 \\
64\end{array}$ & $\begin{array}{r}21696 \\
28 \\
64 \\
53 \\
85\end{array}$ & 5523 & 99.2 & 99.2 \\
\hline 164 & $\begin{array}{r}0-100 \\
100-200 \\
200-400 \\
400-700 \\
700-1000\end{array}$ & $\begin{array}{r}1767 \\
38 \\
13 \\
6 \\
14\end{array}$ & $\begin{array}{r}0 \\
1 \\
3 \\
16 \\
1\end{array}$ & $\begin{array}{r}9 \\
13 \\
51 \\
170 \\
9\end{array}$ & $\begin{array}{r}15 \\
14 \\
8 \\
12 \\
0\end{array}$ & $\begin{array}{r}1791 \\
66 \\
75 \\
204 \\
24\end{array}$ & $\begin{array}{r}7164 \\
264 \\
150 \\
272 \\
32\end{array}$ & 1838 & 85.1 & 98.7 \\
\hline 140 & $\begin{array}{r}0-150 \\
150-350 \\
350-550 \\
550-800 \\
800-1500\end{array}$ & $\begin{array}{r}97 \\
1 \\
1 \\
4 \\
23\end{array}$ & $\begin{array}{r}2 \\
6 \\
11 \\
26 \\
6\end{array}$ & $\begin{array}{r}33 \\
97 \\
148 \\
83 \\
36\end{array}$ & $\begin{array}{l}8 \\
5 \\
3 \\
7 \\
8\end{array}$ & $\begin{array}{r}140 \\
109 \\
163 \\
120 \\
73\end{array}$ & $\begin{array}{r}373 \\
218 \\
326 \\
192 \\
42\end{array}$ & 126 & 20.8 & 69.3 \\
\hline
\end{tabular}

(Ortner et al. 1978, The Ring Group 1981, Wiebe 1982). This is partly due to Slope Water species, which descend to colder layers in order to maintain their temperature environment. The higher zooplankton biomass (156 $\mathrm{mg}$ wet weight $\mathrm{m}^{-3}$ ) in the upper $100 \mathrm{~m}$ of the core of our eastern North Atlantic eddy compared to the surrounding water (72 to $110 \mathrm{mg} \mathrm{m}^{-3}$; Table 2) coincided with a higher phytoplankton biomass (Lochte \& Pfannkuche 1987). This may be due to the age - only 1 mo - of the eddy where some typical ageing processes had not yet developed.
Lower total numbers of organisms per gram wet weight in the $300 \mathrm{~mm}$ net hauls at various depths in the centre of the eddy compared to the surrounding water (Table 2) were at least partly due to high individual numbers of amphipods and medusae in the core's upper $100 \mathrm{~m}$ and to the high amount of large Limacina retroversa at depth between 100 and $400 \mathrm{~m}$ (Fig. 1; Table 3). The spatial distribution pattern of the euthecosomatous pteropod L. retroversa revealed remarkable ontogenetic separation which has not previously been reported and warrants more detailed discussion.
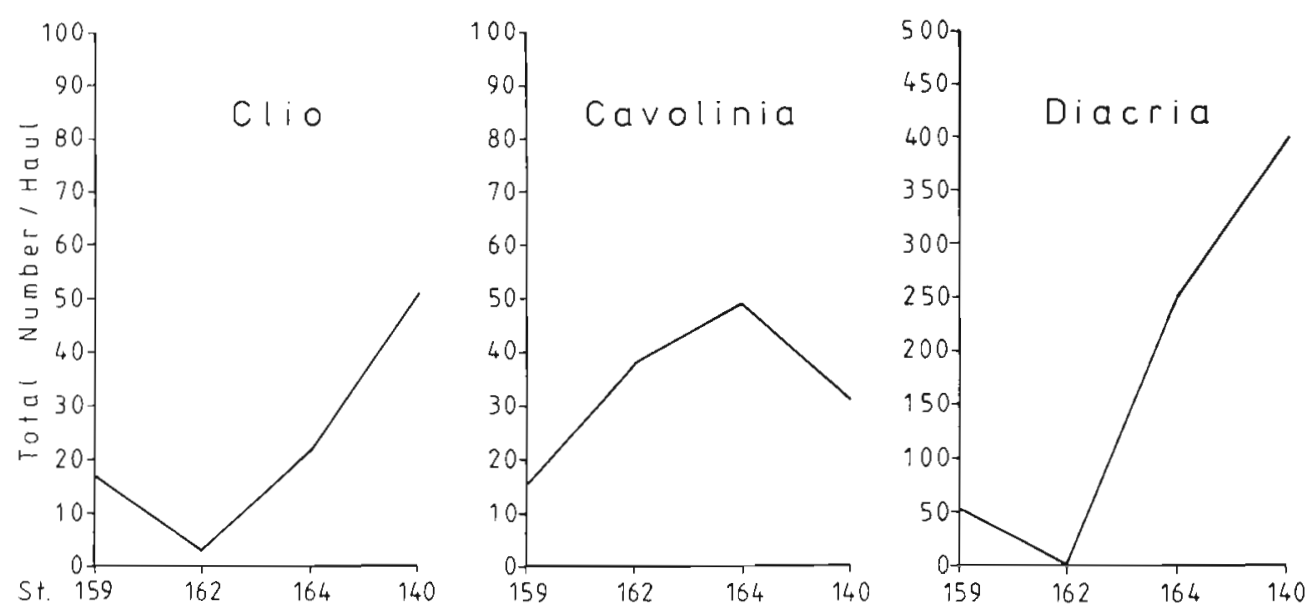

Fig. 2. Distribution of pteropod genera by means of total numbers/haul (100 $\mu \mathrm{m}$ nets and all depth intervals) at the different stations. Cavolinia spp. abundances show a reverse occurrence compared to Clio spp. and Diacria spp. 
Table 6. Absolute abundances and calculated numbers per $100 \mathrm{~m}^{3}$ of planktonic foraminifers at the different tow intervals $[100$ um net). qui: Globigerina quinqueloba; bul: Globigerina bulloides; inf: Globorotalia inflata; hir: Globorotalia hirsuta; ten: Globigerionoides tenellus; pel: Hastigerina pelagica; tru: Globorotalia truncatulinoides; hum: Turborotalita humilis; inc: Neogloboquadrina incompta; glu: Globigerinita glutinata; sci: Globorotalia scitula; fal: Globigerina falconensis; rub: Globigerinoides ruber; uni: Orbulina universa; uvu: Globigerinita uvula; n: number of specimens per sample; $\mathrm{n} 100 \mathrm{~m}^{-3}$ : specimens per $100 \mathrm{~m}^{3}$

\begin{tabular}{|c|c|c|c|c|c|c|c|c|c|c|c|c|c|c|c|c|c|c|}
\hline Stn & $\begin{array}{l}\text { Depth } \\
\text { (m) }\end{array}$ & $q u i$ & inc & bul & glu & inf & $s C i$ & hir & $f a l$ & ten & $r u b$ & pel & uni & tru & uru & hum & $\mathrm{n}$ & $\frac{n}{100 m^{-3}}$ \\
\hline \multirow[t]{5}{*}{159} & $0-100$ & 191 & 327 & 827 & 241 & 58 & 15 & 9 & 5 & 1 & 1 & 0 & 1 & 0 & 1 & 0 & 1677 & 6708 \\
\hline & $100-200$ & 0 & 45 & 0 & 71 & 8 & 36 & 15 & 0 & 0 & 0 & 0 & 0 & 1 & 0 & 2 & 178 & 712 \\
\hline & $200-400$ & 0 & 0 & 0 & 0 & 28 & 46 & 8 & 0 & 0 & 0 & 1 & 0 & 0 & 1 & 0 & 84 & 168 \\
\hline & $400-700$ & 0 & 0 & 0 & 0 & 29 & 68 & 20 & 0 & 0 & 0 & 3 & 0 & 3 & 0 & 0 & 123 & 165 \\
\hline & $700-1000$ & 0 & 0 & 0 & 0 & 25 & 32 & 4 & 0 & 0 & 0 & 0 & 0 & 0 & 0 & 0 & 61 & 81 \\
\hline \multirow[t]{5}{*}{162} & $0-100$ & 234 & 622 & 610 & 239 & 68 & 4 & 2 & 4 & 7 & 3 & 0 & 0 & 0 & 0 & 1 & 1794 & 7176 \\
\hline & $100-200$ & 0 & 34 & 0 & 29 & 4 & 13 & 2 & 0 & 0 & 0 & 0 & 0 & 0 & 0 & 0 & 82 & 328 \\
\hline & $200-400$ & 0 & 0 & 0 & 0 & 7 & 20 & 10 & 0 & 0 & 0 & 0 & 0 & 0 & 0 & 0 & 37 & 74 \\
\hline & $400-700$ & 0 & 0 & 0 & 0 & 20 & 21 & 5 & 0 & 0 & 0 & 1 & 0 & 0 & 0 & 2 & 49 & 65 \\
\hline & $700-1000$ & 0 & 0 & 0 & 0 & 5 & 13 & 4 & 0 & 0 & 0 & 0 & 0 & 0 & 0 & 1 & 23 & 30 \\
\hline \multirow{5}{*}{164} & $0-100$ & 287 & 734 & 1353 & 368 & 184 & 6 & 4 & 0 & 7 & 2 & 0 & 0 & 1 & 0 & 0 & 2946 & 11784 \\
\hline & $100-200$ & 0 & 217 & 0 & 310 & 81 & 18 & 7 & 0 & 0 & 0 & 0 & 0 & 0 & 0 & 0 & 633 & 2532 \\
\hline & $200-400$ & 0 & 0 & 0 & 0 & 21 & 34 & 9 & 0 & 0 & 0 & 0 & 0 & 0 & 0 & 0 & 64 & 128 \\
\hline & $400-700$ & 0 & 0 & 0 & 0 & 38 & 171 & 42 & 0 & 0 & 0 & 5 & 0 & 0 & 0 & 0 & 256 & 342 \\
\hline & $700-1000$ & 0 & 0 & 0 & 0 & 50 & 100 & 20 & 0 & 0 & 0 & 1 & 0 & 0 & 1 & 0 & 172 & 229 \\
\hline \multirow[t]{5}{*}{140} & $0-150$ & 307 & 657 & 1175 & 970 & 220 & 41 & 14 & 12 & 12 & 2 & 0 & 5 & 1 & 0 & 3 & 3419 & 9917 \\
\hline & $150-350$ & 0 & 177 & 0 & 290 & 77 & 133 & 52 & 0 & 0 & 0 & 0 & 0 & 1 & 0 & 0 & 730 & 1460 \\
\hline & $350-550$ & 0 & 0 & 0 & 0 & 43 & 108 & 20 & 0 & 0 & 0 & 0 & 0 & 0 & 0 & 0 & 171 & 342 \\
\hline & $550-800$ & 0 & 0 & 0 & 0 & 60 & 94 & 27 & 0 & 0 & 0 & 3 & 0 & 0 & 0 & 0 & 184 & 294 \\
\hline & $800-1500$ & 0 & 0 & 0 & 0 & 411 & 399 & 55 & 0 & 0 & 0 & 5 & 0 & 1 & 0 & 1 & 872 & 498 \\
\hline
\end{tabular}

The small amount of large Limacina retroversa in the $100 \mu \mathrm{m}$ nets may be attributed to their ability to escape as these nets were towed at a lower speed. However, quite apart from the causes for the divergent findings in the different mesh-sizes, the vertical distribution pattern in the $300 \mu \mathrm{m}$ nets in the core of the eddy was unusual. L. retroversa is an epiplanktonic pteropod of subpolar and transitional waters and most common in the upper $150 \mathrm{~m}$ of the water column (Bé \& Gilmer 1977), but may occupy also deeper waters down to $500 \mathrm{~m}$ (Pafort-van lersel 1985). Diel vertical migrations have been observed by several investigators (Chen \& Bé 1964, Wormuth 1985, Pafort-van Iersel 1985). They seem to be restricted to a maximum of $100 \mathrm{~m}$ depth difference (Wormuth 1985). L. retroversa tolerates maximum surface temperatures from 2 to $19^{\circ} \mathrm{C}$ with an optimum range between 7 and $12{ }^{\circ} \mathrm{C}$ and salinities from 31 to $36 \%$ (Bigelow 1926, cited in Bé \& Gilmer 1977). Water column abundances in the western North Atlantic have been reported to be fairly variable, in addition to showing distinct seasonal fluctuations (Wormuth 1985).

The eastern North Atlantic environment differs from that in the western part, where temperatures and salinities are somewhat higher. Gradients between Slope Water and the Sargasso Sea are distinctly steeper than between the waters north and south of the Polar
Front. This is exemplified when comparing temperatures and salinities in central and ambient surface waters of the present eastern North Atlantic eddy with those from Gulf Stream cold-core ring 'Bob', which was investigated in the same season and was of similar age (The Ring Group 1981) (Table 7).

As a cold-water herbivorous species Limacina retroversa represents a Slope Water indicator in Gulf Stream cold-core rings (The Ring Group 1981, Wormuth 1985). It disappears within the first 5 mo after ring formation when the upper $100 \mathrm{~m}$ have been warmed up and the phytoplankton standing stock has decreased. On the other hand, in the eastern North Atlantic, L. retroversa occurs regularly south of the Polar Front. The most recent biogeographical distribution map (Bé \& Gilmer 1977) separates 2 areas of different abundances: a northern area, where $L$. retroversa is reported as 'common', and a southern area where it is 'present'. The boundary largely coincides with the course of the Polar Front in the eastern North Atlantic.

These observations may explain the higher standing stock of Limacina retroversa in the eddy core compared with the peripheral areas and reference sites (Tables 3 $\& 5$ ), if we assume that the eddy had entrapped high numbers at the Polar Front during its formation. Moreover, the distinctly larger standing stock at all 

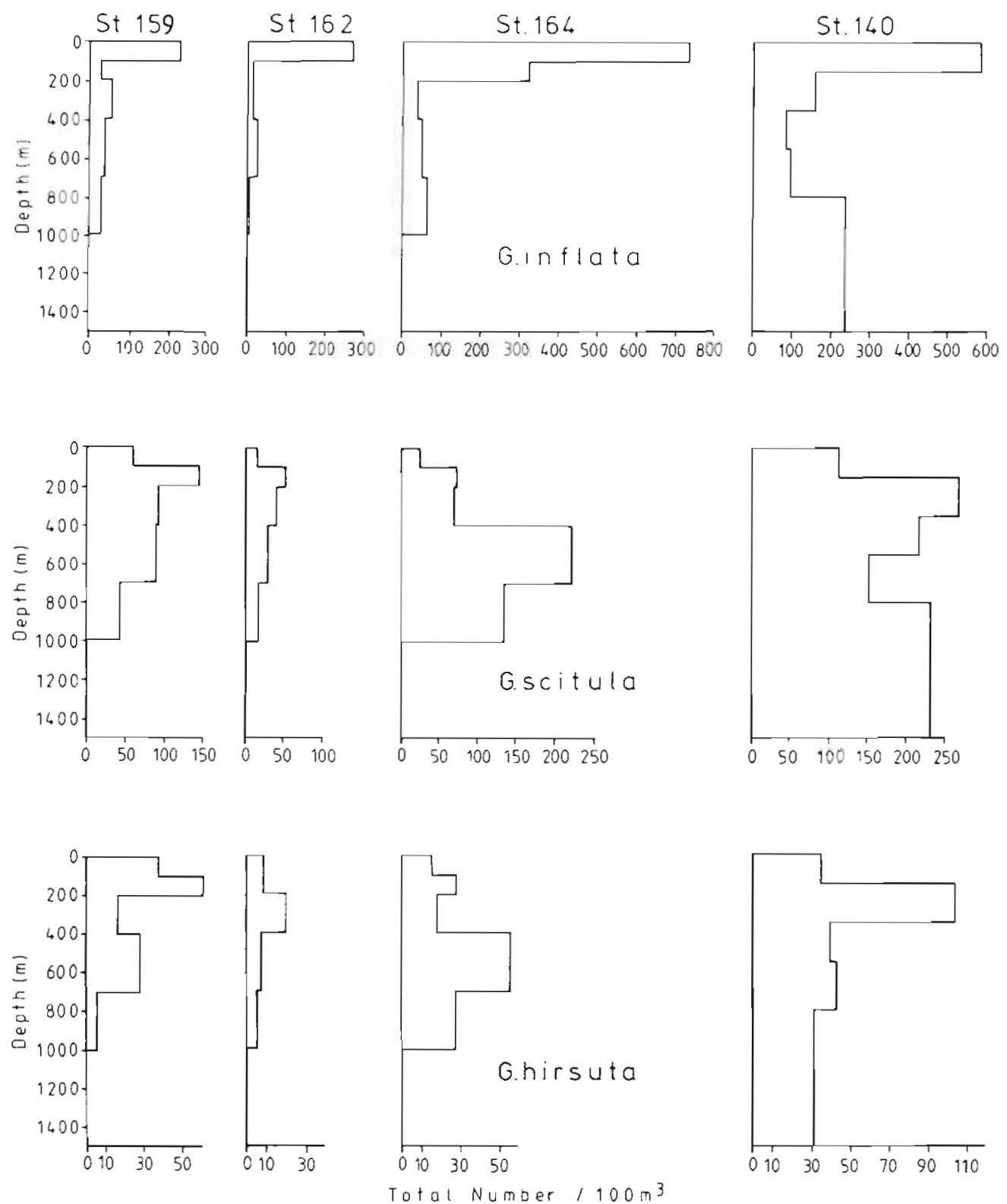

Fig. 3. Distribution of globorotaliid species by total numbers per $100 \mathrm{~m}^{3}$ at the different depth intervals (100 $\mu \mathrm{m}$ nets). The low numbers at core Stn 162 contrast the high abundances in the peripheral water mass (Stns 159, 164) and at reference Stn 140

sites in the eastern North Atlantic compared with those reported from the western North Atlantic (The Ring Group 1981, Wormuth 1985) are explained by the more favourable environmental conditions. A seasonal effect may be less important, considering that the highest concentrations of $L$. retroversa in the eddy core (Table 3) were about 10 times higher than in Gulf Stream ring 'Bob'.

Considering the almost monospecific pteropod assemblage in the eddy core (Tables $3 \& 5$ ), it is interesting to compare the paper by Cifelli \& McCloy (1983). These authors described a sample from Stn 44, Chain 105 ship-cruise (approx. $47^{\circ} \mathrm{N}, 22^{\circ} \mathrm{W}$ ) which is quite close to our investigated area. The pteropod assemblage consisted exclusively of Limacina retroversa. This observation may indicate the occurrence of an eddy at that time.

The unusual vertical distribution pattern of Limacina retroversa detected in the $300 \mu \mathrm{m}$ nets is difficult to explain. Several hypotheses may be considered. $L$. retroversa feeds on both dinoflagellates and diatoms (Morton 1954, Van der Spoel 1967), including species which are toxic for other organisms, e.g. fish (White 1977). Lochte \& Pfannkuche (1987) found large amounts of phytoplankton. Dinoflagellates dominated in the upper $40 \mathrm{~m}$ of the eddy-core. It seems unlikely 
Table 7. Surface temperature and salinity in the core and the ambient water masses of the investigated Polar Front eddy in comparison to a similar aged Gulf Stream cold-core ring of the same season (data from Mittelstaedt 1987 and The Ring Group 1981)

\begin{tabular}{|c|c|c|c|c|}
\hline & \multicolumn{2}{|c|}{ Surface temperatures $\left({ }^{\circ} \mathrm{C}\right)$} & \multicolumn{2}{|c|}{ Surface salinities (\%a) } \\
\hline & Core & Ambient & Core & Ambient \\
\hline $\begin{array}{l}\text { Gulf Stream ring "Bob" } \\
1 \text { mo old April } 1977\end{array}$ & $15-18$ & $>21$ & $35.8-36.0$ & $>36.4$ \\
\hline $\begin{array}{l}\text { Polar Front eddy } 1 \text { mo } \\
\text { old May } 1985\end{array}$ & $12.5-13$ & $>13$ & $35.2-35.3$ & $>35.6$ \\
\hline
\end{tabular}

that a lack of food caused the descent of the large $L$. retroversa. We suggest that they resided within their optimum temperature range of about 7.5 to $10^{\circ} \mathrm{C}$. In the peripheral region of the eddy, optimum temperatures for large specimens occurred only below $400 \mathrm{~m}$ depth (Table 3). The distance from below $400 \mathrm{~m}$ to the phytoplankton standing stock in the surface layer cannot be covered by vertical migration. The feeding behaviour of $L$. retroversa provides some evidence against diel migrations over large depth intervals (Gilmer \& Harbison 1986). Whether or not a diel vertical migration of $L$. retroversa over distances greater than $100 \mathrm{~m}$ occurred in the eddy-core could not be tested as no day/night data for comparison were available. The deep occurrence of the large specimens may alternatively be interpreted as a descent related to the species' life cycle. In the western North Atlantic adults of species such as L. inflata, L. bulimoides, and Styliola subula can be found in deeper water, mainly below $200 \mathrm{~m}$, while juveniles occur in high abundances above $100 \mathrm{~m}$ (Almogi-Labin et al. unpubl.). This suggests that both food supply and temperature play an important role throughout the lifecycle.

Salinity can be expected to be unimportant for the spatial distribuion of Limacina retroversa at the eastern North Atlantic stations as it never exceeded the species' tolerance range, in contrast to conditions in the Sargasso Sea (Table 7).

Summarizing our observations we speculate that Limacina retroversa was entrapped by the eddy at the Polar Front and transported further southeast producing higher absolute abundances in the core than in the ambient water. The ontogenetic separation was mainly due to the particular temperature gradients in the eddy water column causing a descent of large specimens of $L$. retroversa

The geographical distribution of the foraminifer Globigerina bulloides covers a wide area of the North Atlantic between $38^{\circ} \mathrm{N}$ and $75^{\circ} \mathrm{N}$, often forming $>50 \%$ of the foraminiferal assemblage (Bé \& Tolderlund 1971). In the investigated area the relative abundances of this species varied from $49.3 \%$ at Stn 159 , (45.9\% at $\operatorname{Stn} 164$ ), to 34.0 and $34.3 \%$ at Stns 162 and
140 respectively. This reflects the observation by Bé (1977), who stated the area of maximum abundance has an irregular pattern' in the North Atlantic. In addition, this irregular pattern can be influenced by the reproductive cycle of $G$. bulloides which seems to be linked to the lunar cycle (Hemleben unpubl. data). Unfortunately, the day of collection at the eddy core coincided with a new moon which may have caused a different superimposed pattern. The distribution of deep-living non-spinose species (G. inflata, G. scitula, and $G$. hirsuta) is unexpected. These phytoplankton feeders should occur in higher abundances in the eddy core due to the high amount of phytoplankton. This was not observed. However, a clear explanation can be found by considering their yearly life cycle. The high abundance of phytoplankton will indeed enhance their metabolism, but as these favourable biological properties can change drastically within weeks, the population size will not be greatly affected.

\section{CONCLUSIONS}

Biogeographical regions north and south of the Polar Front are more uniformly developed than those separated by the Gulf Stream in the west. In addition, eddies may be less abundant in the eastern North Atlantic. Thus, we suggest Polar Front eddies in the eastern North Atlantic, in contrast to Gulf Stream rings, to be of minor importance as large-scale interaction sites for pelagic communities or as vehicles to overcome natural biogeographical boundaries. Nevertheless, when they occur they do have an effect on the horizontal and vertical zooplankton distribution as exemplified by Limacina retroversa.

We are aware that we observed the eddy for $2 \mathrm{~d}$ which represents only a 'snapshot'. In addition, the methods we used were certainly not sufficient for a complete evaluation of dynamic processes related to eddy systems (see Angel \& Fasham 1983). However, it is a beginning in studying the biology of these complicated structures in the eastern North Atlantic. 
Acknowledgements. The authors thank E. Mittelstaed from the Deutsches Hydrographisches Institut, Hamburg, and the master and crew of RV Meteor for their cooperation. We are also indebted to $\mathrm{Ch}$. Schumacher for her assistance during the cruise and help in sorting the $300 \mathrm{um}$ samples. Furthermore, we thank our colleagues J. Bijma, D. Coyle, and K. Lochte for critically reading and $\mathrm{A}$. Lupke for typing the manuscript. The investigations were funded by the Ministry of Science and Technology of the Federal Republic of Germany (MFU 0544/9) and the Deutsche Forschungsgemeinschaft (He 697/4-1).

\section{LITERATURE CITED}

Angel, M. V., Fasham, M. J. R. (1983). Eddies and biological processes. In: Robinson, A. R. (ed.) Eddies in marine science. Springer-Verlag, New York, p. 492-524

Bé, A. W. H. (1977). An ecological, zoogeographic and taxonomic review of recent planktonic Foraminifera. In: Ramsay, A. T. S. (ed.) Oceanic micropalaeontology, Vol. 1. Academic Press, New York, p. 1-100

Bé, A. W H., Gilmer, R. W. (1977). A zoogeographic and taxonomic review of euthecosomatous Pteropoda. In: Ramsay, A. T. S. (ed.) Oceanic micropalaeontology, Vol. 1. Academic Press, New York, p. 733-808

Bé, A. W. H., Tolderlund, D. S. (1971). Distribution and ecology of living planktonic Foraminifera in surface waters of the Atlantic and Indian Oceans. In: Funnel, B. M., Riedel, W. R. (ed.) The micropalaeontology of oceans. Cambridge University Press, Cambridge, p. 105-149

Bigelow, H. B. (1926). Plankton of the offshore waters of the Gulf of Maine. Bull. U.S. Fish. Commn 40: 1-509

Chen, C., Bé, A. W. H. (1964). Seasonal distributions of euthecosomatous pteropods in the surface waters of five stations in the Western North Atlantic. Bull. mar. Sci. Gulf Carribb. 14: 185-220

Cifelli, R., McCloy, C. (1983). Planktonic Foraminifera and euthecosomatous pteropods in the surface waters of the North Atlantic. J. Foraminiferal Res. 13: 91-107

Gilmer, R. W., Harbison. G. R. (1986). Morphology and field behaviour of pteropod molluscs: feeding methods in the families Cavoliniidae, Limacinidae and Peraclididae (Gastropoda: Thecosomata). Mar. Biol. 91: 47-57

Kupferman, S. L., Becker, G. A., Simmons, W. F., Schauer, U.,
Marietta, M. G., Nies, H. (1986). An intense cold core eddy in the North-East Atlantic. Nature, Lond. 319: 474-477

Lochte, K., Pfannkuche, O. (1987). Cyclonic cold-core eddy in the eastern North Atlantic II. Nutrients, bacterio- and phytoplankton. Mar. Ecol. Prog. Ser. 39: 153-164

Mittelstaedt, E. (1987). Cyclonic cold-core eddy in the eastern North Atlantic. I. Physical description. Mar. Ecol. Prog. Ser 39: $145-152$

Morton, J. E. (1954). The biology of Limacina retroversa. J. mar. biol. Ass. U. K. 33: 297-312

Ortner, P. B., Wiebe, P. H., Haury, L., Boyd, S. (1978). Variability in zooplankton biomass distribution in the northern Sargasso Sea: The contribution of Gulf Stream cold core rings. Fish. Bull. U.S. 76: 323-334

Pafort-van Iersel, T. (1985). Contributions to pelagic zoogeography of the Mid North Atlantic Ocean. Ph. D. thesis, Inst. of Taxonomic Zoology, Univ. Amsterdam

The Ring Group (1981). Gulf Stream cold-core rings: their physics, chemistry, and biology. Science 212: 1091-1100

Tranter, D. J. (1962). Zooplankton abundance in Australian waters. Aust. J. mar. Freshwat. Res. 13: 106-142

Van der Spoel, S. (1967). Euthecosomata, a group with remarkable developmental stages (Gastropoda, Pteropoda). Noorduijn en Zoon N.V., Gorinchem

Weikert, H., John, H.-C. (1981). Experiences with a modified Bé multiple opening-closing plankton net. J. Plankton Res. 3: $167-176$

White, A. W. (1977). Dinoflagellate toxins as probable cause of an Atlantic Herring (Clupea harengus) kill, and pteropods as apparent vector. J. Fish. Res. Bd Can. 34: 2421-2424

Wiebe, P. H. (1976). The biology of cold-core rings. Oceanus 19: 69-76

Wiebe, P. H. (1982). Rings of the Gulf Stream. Scient. Am. 246: $60-70$

Wiebe, P. H., Flierl, G. R. (1983). Euphausid invasion/dispersal in Gulf Stream cold-core rings. Aust. J. mar. Freshwat. Res. 34: 625-652

Wiebe, P. H., Hulburt, E. M., Carpenter, E. J., Jahn, A. E., Knapp, G. P. III, Boyd, S. H., Ortner, P. B., Cox, J. L. (1976). Gulf Stream cold core rings: large-scale interaction sites for open ocean plankton communities. Deep Sea Res. 23: 695-710

Wormuth, J. H. (1985). The role of cold-core Gulf Stream rings in the temporal and spatial patterns of euthecosomatous pteropods. Deep Sea Res. 32: 773-788 